\title{
Construction of an instrument for the prognostic evaluation of elderly persons in intensive care units
}

Ivanilda Lacerda Pedrosa' Djacyr Magna Cabral Freire' Rodolfo Herberto Schneider ${ }^{2}$

\section{Abstract}

Objective: To create an instrument for the prognostic evaluation of elderly patients hospitalized in an intensive care unit. Methods: A cohort study, with prospective data collection, which included elderly persons aged 60 years or older, was carried out in the city of João Pessoa, in the state of Paraíba, Brazil. Data collection was performed using an instrument created from a pilot study and the Katz Index. Poisson's regression was used for data analysis. This technique estimates relative risk, retaining variables with $p \leq 0.10$ in the instrument, and ensures biological plausibility. The classification of risk of death was performed using quartile analysis, confirmed by the Receiver Operator Characteristic (ROC) curve. Results: 205 elderly patients with an average age of 74.6 years and a 59\% risk of mortality, were included. Of the total sample and based on the scores, $16.6 \%$ of elderly persons had a low risk of developing death, $23.9 \%$ were at moderate risk, $40 \%$ had a high risk, and $19.5 \%$ exhibited a very high risk of death. The positive predictive value of the instrument was $77 \%$ and the negative value was $67.5 \%$, with a concordance index of 0.78 . The cutoff score of the instrument was 9 points or over. The sensitivity was $77.7 \%$ and the specificity was $66.7 \%$. Conclusions: The instrument developed may be useful in the identification of elderly people with risk factors who require increased care. The instrument described can therefore be applied in Brazilian intensive care units.

Keywords: Elderly.

Prognosis. Intensive Care

Units. Patients. Evaluation.

\footnotetext{
Universidade Federal da Paraíba, Centro de Ciências da Saúde. João Pessoa, PB, Brasil.

2 Pontifícia Universidade Católica do Rio Grande do Sul (PUCRS), Programa de Pós-Graduação em Gerontologia Biomédica do Instituto de Geriatria e Gerontologia (IGG). Porto Alegre, RS, Brasil.
} 


\section{INTRODUCTION}

With increased population aging and greater longevity accompanied by the exacerbation of noncommunicable chronic diseases, more and more elderly persons are becoming users of hospital services and consequently being hospitalized in intensive care units ${ }^{1,2}$.

The overall rate of mortality in adult intensive care units (ICUs) is between 10 and $56 \%{ }^{3,4}$ while the mortality of the elderly in such units ranges from 28 to $62 \% 0^{5,6}$.

This population group, which is generally characterized by a high prevalence of chronic diseases and reduced organic reserve, presents a greater demand for ICU beds and evolves more easily to a critical state, resulting in greater costs when hospitalized in these units.

To provide care to such individuals, multiprofessional teams working in the ICU must have specific knowledge about the needs of the elderly and focus their actions on attending to their specific needs and the needs of their families, while also accompanying the advances of the complex technology that these units contain.

The severity of the condition of individuals leads medical professionals to think about their prognosis and to seek measures that evaluate such severity, as well as considering whether the treatment instituted will be successful, or if the search for a cure for the patient should be suspended. This means that measurement is a constant challenge which, if effectively performed, can facilitate decision-making by the health team and family members ${ }^{7}$.

In a study carried out in 2015, Pedrosa et al. ${ }^{1}$ found that the combination of acute and chronic diseases, together with the physiological limitations resulting from the aging process, can interfere with the treatment of elderly persons in the ICU, resulting in a more negative prognosis.

Literature remains conflicting in terms of demonstrating whether the instruments and scales of evaluation and prognosis currently used in younger populations are also the most adequate for the elderly population.
Studies support the development and validation of new indices aimed at elderly patients hospitalized in ICUs, which consider, in addition to survival, the functional and cognitive status of such individuals following hospital discharge, and argue that the creation of these indices can support decision making in the ICU, respecting the preferences of patients ${ }^{8,}$.

In the midst of these challenges, and due to the high percentages of elderly people in the population, a proportion which increases considerably in ICUs, there is a need for greater targeting of care through the introduction of new strategies that offer the required treatment, so reducing hospitalization and providing more resolutive approaches for the health problems of the elderly ${ }^{10}$.

Therefore, to contribute to the care of the elderly in ICUs, the present study aimed to construct a tool for the prognostic evaluation of elderly patients admitted to an intensive care unit.

\section{METHOD}

An exploratory cohort study involving elderly ICU patients, with data collected prospectively, was carried out in four hospitals with ICU services that offered care to the severely ill from the public health network of the city of João Pessoa, Paraíba, Brazil. One of these was a teaching hospital with twelve beds, one was a military hospital with seven beds, one was a municipal hospital with ten beds and one was a state hospital with eight beds. Together these hospitals offer 37 beds for intensive care admission.

The sample was selected for convenience and based on free demand for each service. It consisted of elderly individuals aged 60 years or older admitted to the ICUs of the hospitals included in the study, with a length of stay in the unit equal or superior to 24 hours, and irrespective of their educational level or physical and mental status. Elderly patients who died within the first 24 hours; who were transferred to ICUs from hospitals that were not part of the study; and who were neither discharged nor died during the period determined for data collection were excluded from the study, along with the first hospitalizations of those subsequently readmitted to the ICU. The sample size calculation was performed according to guidelines established in literature, 
which suggest that studies using regression analysis are based on a quantitative of at least 10 outcomes per predictor variable in the final instrument ${ }^{11}$, giving a total sample of 170 patients.

Data collection was performed from the beginning of December 2012 to the end of June 2013, using the instrument constructed from the pilot study and the Katz scale ${ }^{12}$, with the objective of evaluating the functional capacity of the elderly. Three classification categories were used: independent, partially dependent and totally dependent.

A cross-sectional pilot study was applied to 20 elderly patients admitted to two ICUs from the institutions included in the study. The construction of the instrument for the pilot study was aimed at identifying the clinical and demographic characteristics of elderly individuals in these units and the approximation of the variables to be included in the data collection instrument used in the study. While the results of the pilot study were not inserted in this study, the findings showed that this instrument allowed approximation to reality and the identification of the most important variables for the construction of the data collection instrument used in this study.

The "worst" data from the first 24 hours of the patient in the ICU were collected from medical records. To achieve this, the data which most effectively revealed the extent of the severity of the patient's condition, such as highest temperature, were gathered from the results observed and recorded by the medical team. This measure is justified by the fact that the data collected in this period reveals the status of the patient without the interference of the measures instituted in the ICU, and it is when the most severe disorders with the worst psychological deviations are observed ${ }^{3,6,13}$.

In the case of readmission to the ICU, records of the previous hospitalization were disregarded. In sedated patients, the Glasgow Coma Scale was used to classify state of consciousness immediately before sedation.

The strategy for the construction of the data collection instrument was based on the problems raised in the pilot study, the variables contemplated in previously validated severity indexes applied to adult patients hospitalized in ICUs, and variables highlighted by several previously published studies, which address factors potentially related to the outcome of elderly persons hospitalized in ICUs. Biological plausibility, or in other words whether the findings were consistent with the state of elderly persons hospitalized in the ICU, was also considered, as was the clinical experience of the researchers of factors related to the prognosis of elderly persons in ICUs and which are considered important for this age group. The prognosis of the elderly in the ICU refers to anticipated knowledge or judgment about the evolution of the disease or patient, and the chances of a cure.

Variables related to clinical history were collected from family information and medical records, and were included in the data collection instrument. These were: age group, gender, length of previous ICU stay, hospitalization in the last year, comorbidities, functional capacity, previous cognitive decline, previous history of delirium and medication use, as well as variables related to the reason for hospitalization: type of hospitalization, Glasgow coma scale, invasive procedures performed in the ICU, vital signs, 24 hour diuresis, drugs used in the ICU, ventilatory modality, $\mathrm{FiO}_{2}$ percentage, $\mathrm{O}_{2}$ saturation, $\mathrm{Ph}$ value and blood gases, laboratory tests and length of stay in the ICU.

This information was obtained by the researchers during the working day and always at visiting times, so that the family could be approached in order to obtain the clinical history of the patient, followed by the study of medical records to obtain data related to laboratory tests, demographic information, and clinical data relating to the admission of the elderly person in the first twenty-four hours.

The process of constructing the prognostic evaluation instrument followed the steps of categorization of the variables and statistical analysis. Several variables were collected as absolute values, and were then categorized following criteria adopted in literature and articles that deal with the subject, considering the physiological and pathological peculiarities inherent in the elderly individuals.

The continuous variables were described by mean and standard deviation or median and interquartile range, and the categorical variables were described 
by count data and percentages and compared by Pearson's chi-square test.

The Poisson regression technique was used to estimate the Relative Risk (RR), a measure of the association between a particular factor and the risk of a given outcome, which in this case was the outcome of hospital discharge due to improvement or death ${ }^{14}$. This indicates the chance of risk in the exposed and non-exposed groups, thus expressing by how many times the risk is greater or lower in the exposed group than in the unexposed group.

Univariate Poisson regression analysis was therefore performed in the construction of the prognostic evaluation instrument, and included variables with a value of $p<0.20$ or with major biological plausibility. It was followed by Poisson multivariate analysis, retaining only variables with $p \leq 0.10$ in the instrument.

In order to determine the discrimination capacity of the instrument constructed, the $\mathrm{C}$-index (concordance) was used. This value is equivalent to the area under the ROC (Receiver Operator Characteristic) curve, allowing the expression of the relationship between sensitivity and specificity, that is, the capacity to distinguish the final outcome.

The prognostic evaluation instrument was constructed, generating a score for the included variables, based on the point estimate of $R R$ and the confidence interval, determined by the Poisson regression technique, with variables with major biological plausibility also considered.

The classification of risk of death was also elaborated, using quartile analysis, confirmed by the ROC curve, and the Kaplan-Meier curve was constructed in order to evaluate time until the occurrence of death in the ICU.

All the phases of the study complied with Resolution 466/12 of the National Health Council of the Department of Health ${ }^{15}$, and the project was approved by the Ethics Research Committee of the Pontifícia Universidade Católica do Rio Grande do Sul, under Plataforma Brasil number 186.415.

\section{RESULTS}

A total of 555 patients were admitted to the ICUs of the study during the period from December 1, 2012 to June 20, 2013, of whom 252 (45.4\%) were elderly. Data was collected from 233 of these subjects, with 28 individuals then eliminated due to transfer, incomplete data or a stay of less than 24 hours in the ICU. The total sample of the study was therefore composed of 205 elderly people, $30.7 \%$ of whom were from the teaching hospital, $25.8 \%$ from the military hospital, $28.7 \%$ from the municipal hospital and $14.6 \%$ from the state hospital.

The mean age of the total sample was $74.6( \pm$ 9.04) years, with the youngest individual aged 60 and the oldest person aged 96 . The length of stay in the ICU ranged from 01 to 126 days of hospitalization, with a median of 11 days $\left(25^{\text {th }}\right.$ percentile $=5$ days, $75^{\text {th }}$ percentile $=22$ days). Hospitalization time ranged from 10 to 114 days, with a median of two days $\left(25^{\text {th }}\right.$ percentile $=1$ day, $75^{\text {th }}$ percentile $=9$ days). Of the total sample, the outcome of 121 (59.02\%) elderly patients was death.

Table 1 shows the Poisson multivariate analysis, including only variables that obtained a statistical significance with a value of $p<0.10$ included. Due to their statistical significance, these variables were included in the final prognostic evaluation instrument.

Based on the point estimate of RR and the confidence interval determined by Poisson regression, together with biological plausibility, a score was generated for the variables included, with a total of 33 points, and is set out in table 2 .

Table 3 shows the risk of mortality of the elderly in the ICU according to score and classification of risk, based on quartile analysis and confirmed by the ROC curve. Of the total sample and based on the scores, $16.6 \%$ of the elderly persons were low risk, $23.9 \%$ presented moderate risk, $40 \%$ were high risk and $19.5 \%$ had a very high risk of evolving until death. Corroborating the findings of the scores, the probability of death increases considerably when the score is $\geq 9$ points. 
Table 1. Distribution of variables according to relative risk, confidence interval and $p \leq 0.10$ value, based on Poisson multivariate analysis (n=205). João Pessoa, Paraíba, 2013.

\begin{tabular}{|c|c|c|c|}
\hline Variables & Relative Risk & CI $95 \%$ & $\mathrm{p}$ \\
\hline \multicolumn{4}{|l|}{ Clinical antecedents } \\
\hline Prior delirium & 1.36 & $(1.14-1.63)$ & 0.001 \\
\hline Neoplasms & 1.61 & $(1.20-2.16)$ & 0.002 \\
\hline Use of vasoactive drugs & 1.41 & $(1.13-1.76)$ & 0.002 \\
\hline Heart rate $>100 \mathrm{bpm}^{*}$ & 1.27 & $(1.03-1.57)$ & 0.024 \\
\hline Length of stay in ICU & 1.01 & $(1.00-1.01)$ & 0.006 \\
\hline Glycemia $<70 \mathrm{mg} / \mathrm{dl}$ & 1.40 & $(0.94-2.10)$ & 0.102 \\
\hline \multicolumn{4}{|l|}{ Age range (years) } \\
\hline $60-69$ & 1.00 & - & - \\
\hline $70-79$ & 1.12 & $(0.88-1.43)$ & 0.354 \\
\hline$\geq 80$ & 1.42 & $(1.08-1.86)$ & 0.012 \\
\hline \multicolumn{4}{|l|}{ Ventilatory support } \\
\hline Spontaneous/Catheter & 1.00 & - & - \\
\hline Use of Venturi mask & 1.87 & $(1.15-3.15)$ & 0.018 \\
\hline Invasive Mechanical Ventilation & 1.82 & $(1.09-3.03)$ & 0.022 \\
\hline \multicolumn{4}{|l|}{ Glasgow Coma Scale } \\
\hline Mild: 13 to 15 & 1.00 & - & - \\
\hline Moderate: 9 to 12 & 1.48 & $(1.09-2.01)$ & 0.013 \\
\hline Severe: 3 to 8 & 1.33 & $(1.02-1.73)$ & 0.033 \\
\hline \multicolumn{4}{|l|}{ Reason for hospitalization } \\
\hline Respiratory disorder & 1.86 & $(1.00-3.45)$ & 0.050 \\
\hline Neurological disorder & 1.99 & $(1.07-3.68)$ & 0.029 \\
\hline Cardiac disorder & 1.96 & $(1.08-3.56)$ & 0.028 \\
\hline Gastrointestinal disorder & 2.26 & $(1.19-4.29)$ & 0.013 \\
\hline Renal/metabolic disorder & 0.82 & $(0.28-2.42)$ & 0.723 \\
\hline Infection/sepsis & 1.56 & $(0.84-2.92)$ & 0.162 \\
\hline Surgical procedures & 1.00 & - & - \\
\hline
\end{tabular}

*bpm $=$ beats per minute

Table 2. Variables included in the prognostic evaluation instrument for elderly persons hospitalized in ICUs, based on score ( $\mathrm{n}=205)$. João Pessoa, Paraíba 2013.

\begin{tabular}{ll}
\hline Variables & Score \\
\hline Clinical antecedents & \\
Prior presence of delirium & 2 \\
Neoplasms & 3 \\
Use of vasoactive drugs & 2 \\
Heart rate $>100 \mathrm{bpm} *$ & 2 \\
Glycemia $<70 \mathrm{mg} / \mathrm{dl}$ & 1 \\
\hline Age range (years) & \\
$70-79$ & 1 \\
$\geq 80$ & 2 \\
\hline
\end{tabular}


continued from Table 2

\begin{tabular}{ll}
\hline Variables & Score \\
\hline Ventilatory Support & 2 \\
Use of Venturi mask & 3 \\
Invasive Mechanical Ventilation & \\
\hline Glasgow Coma Scale & 2 \\
Moderate: 9 to 12 & 3 \\
Severe: 3 to 8 & \\
\hline Reason for hospitalization & 2 \\
Respiratory disorder & 2 \\
Neurological disorder & 2 \\
Cardiac disorder & 2 \\
Gastrointestinal disorder & 1 \\
Infection/sepsis & 1 \\
Length of stay in ICU $>6$ days & 33 \\
\hline Total points & 2 \\
\hline
\end{tabular}

*bpm = beats per minute

Table 3. Classification of risk of death for elderly persons hospitalized in ICU based on score and category of risk (n=205). João Pessoa, Paraíba, 2013.

\begin{tabular}{llll}
\hline Score & $\begin{array}{l}\text { Sample } \\
\mathrm{n}=205(\%)\end{array}$ & $\begin{array}{l}\text { Death } \\
\mathrm{n}(\%)\end{array}$ & Category of risk \\
\hline$\leq 6$ & $34(16.6)$ & $05(14.7)$ & Low \\
\hline $7-8$ & $49(23.9)$ & $22(44.9)$ & Moderate \\
\hline $9-11$ & $82(40.0)$ & $58(70.7)$ & High \\
\hline 11 & $40(19.5)$ & $36(90.0)$ & Very high \\
\hline
\end{tabular}

Table created by authors

The discriminatory power of the instrument was demonstrated by the construction of the ROC curve. The positive predictive value was $77 \%$, while the negative predictive value was $67.5 \%$, with a concordance index $C=0.78$ (95\% CI, 0.71-0.84). The cut-off point of the instrument through the ROC curve was $\geq 9$ points. The sensitivity was $77.7 \%$ and specificity was $66.7 \%$ (Figure 1).
Figure 2 shows the distribution of the survival rate of the elderly participants in the study according to length of stay in the ICU. For individuals who remained in the ICU for up to 10 days, the survival rate was $69.8 \%$, with this rate falling to $46.6 \%$, $22.4 \%$ and $10.7 \%$ for those who remained for 20 , 40 and 50 days respectively, as verified by the Kaplan Meier curve. This figure reveals that, as the length of stay of the elderly person in the ICU increases, the probability of survival decreases. 


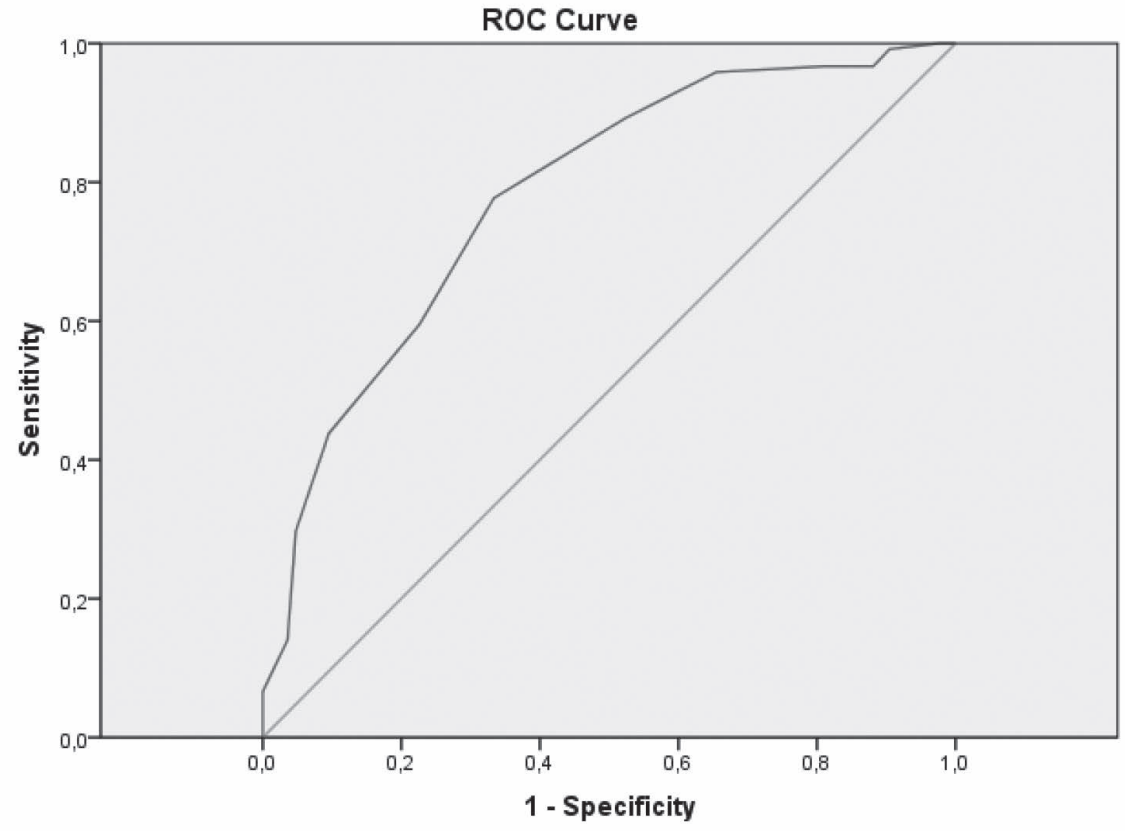

Diagonal segments are produced by ties.

Figure 1. Area under ROC curve in detection of occurrence of mortality of elderly persons in an ICU using the final prognostic evaluation instrument. C=0.78 (CI 95\%; 0.71 - 0.84), (n=205). João Pessoa, Paraíba, 2013.

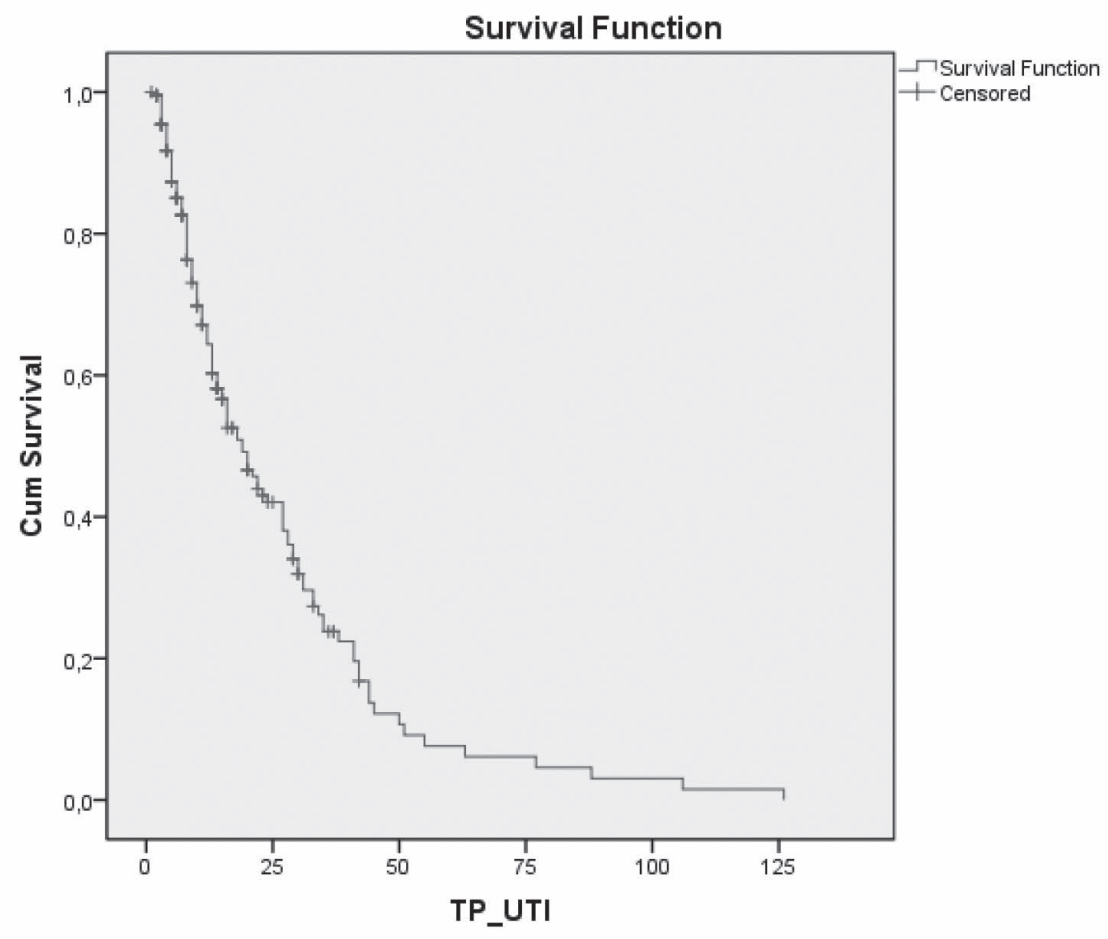

Figure 2. Kaplan-Meier Curve (n=205). João Pessoa, Paraíba, 2013.

TP_ICU $=$ Length of stay in ICU 


\section{DISCUSSION}

The results indicated ten factors which may be associated with a higher risk of mortality for elderly patients hospitalized in ICUs: previous delirium; neoplasms; use of vasoactive drugs; heart rate $>100$ bpm; length of stay in the ICU> 6 days; glycemia $<70 \mathrm{mg} / \mathrm{dl}$; age range $\geq 80$ years; use of Venturi mask or invasive mechanical ventilation (IMV) as ventilatory support; a moderate or severe Glasgow coma scale rating; and respiratory, neurological, cardiac or gastrointestinal disorders as a reason for hospitalization.

The reason for hospitalization presented a significant association with death and a high relative risk of mortality among the elderly persons in the ICU, and was classified by disorders in different body systems. Disorders that affected the gastrointestinal system correlated most closely with death in the ICU, with elderly individuals admitted with pathologies that affected this system having more than twice the risk of an outcome of death than elderly persons who were not exposed to this situation. This corroborates the findings of other authors ${ }^{16}$, who affirmed that the disorders that most affected the elderly in ICUs were neurological, cardiovascular, respiratory, gastrointestinal and renal/metabolic.

Hospitalized elderly persons with a clinical history of neoplasms had a 1.61 times greater risk of death than the elderly who did not have the clinical diagnosis of this disease. Elderly cancer patients are a significant presence in the ICU, and increased age means there is a greater chance that neoplastic disease will be present in more advanced stages ${ }^{17}$.

Just as respiratory disorders were significantly associated with a risk of death risk, so ventilatory support was included in the instrument as a predictor of a worse prognosis, with a high risk of death. Elderly patients who used a Venturi mask were 1.87 times more likely to evolve to death in the ICU and those who used IMV were 1.82 times more at risk than those who did not use such breathing modalities. Previous studies also identified the latter as an important risk factor for the negative prognosis of elderly patients admitted to the ICU ${ }^{18,19}$.
In terms of the Glasgow coma scale, it was observed that elderly persons with a moderate score had a 1.48-fold greater risk of death, while elderly individuals with a score between 3 and 8 had a 1.33 times greater risk.

Regarding age group, elderly persons aged 80 years or more were 1.42 times more likely to evolve to death than younger elderly individuals. Scholars have identified age as a factor related to higher mortality ${ }^{5}$, but warn that age on its own should not be related to a worse prognosis ${ }^{8,9}$. Other associated factors, such as the severity of an acute illness, comorbidities and functional status appear to be more responsible for such an outcome $e^{8,9}$.

The use of vasoactive drugs was identified as another important factor of mortality, with elderly people who used this type of drug during the first 24 hours of hospitalization having a 1.41 times greater chance of death than elderly individuals who did not, corroborating the findings of a previous study cited in literature ${ }^{20}$.

The risk of mortality of elderly persons with a history of delirium was almost double that of elderly persons without such a history. This factor is a major concern as it is a problem that commonly affects the elderly and is often underdiagnosed, and because it is associated with a serious and life threatening condition ${ }^{21}$.

Medical teams should perform careful cardiac monitoring, as elderly patients with a heart rate (HR) higher than $100 \mathrm{bpm}$ are 1.27 times more likely to progress to death, corroborating other findings which affirmed the existence of a "close correlation with $H R$ values, with values above $110 \mathrm{bpm}$ implying an almost 50\% risk of death, and values below 69 bpm being associated with $15 \%$ of deaths" 22 .

Glycemia below $70 \mathrm{mg} / \mathrm{dl}$ was associated with a poor prognosis. The American Association of Clinical Endocrinologists (AACE) and the American Diabetes Association (ADA) propose the need for glycemic control in the ICU, in view of the results of more recent studies which have showed that hypoglycemia also increases mortality. Currently, the AACE and ADA suggest that glycemic levels lower than $100 \mathrm{mg} /$ 
dl should be avoided, and define hypoglycemia as corresponding to values below $70 \mathrm{mg} / \mathrm{dl}$ and severe hypoglycemia to values below $40 \mathrm{mg} / \mathrm{dl}^{23}$.

An ICU stay of longer than six days was also among the variables that presented a risk of an unfavorable outcome in the ICU. This variable was left in the instrument as it was considered an additional risk factor for a negative prognosis for the elderly in the ICU. As it was not possible to assess this variable in the first 24 hours of hospitalization, it was applied to elderly persons with a hospitalization time of more than six days. In a study carried out with elderly patients who developed severe sepsis and septic shock, the length of ICU stay was also related to death ${ }^{13,20}$.

From the identification of the factors related above it was possible to develop a score-based prognostic evaluation instrument using a points scale. The overall score totaled 33 points, and according to the ROC curve, the probability of death increases considerably with scores equal to or greater than 9 points. It should be pointed out that for some variables that are grouped together the score is allocated to only one of the variables, such as age, ventilatory support, Glasgow coma scale classification and reason for hospitalization.

In addition to the aforementioned factors, the instrument included the variables age range, categorized from 70 to 79 years, and a reason for hospitalization of infection/sepsis. We chose to include these variables as we consideried them to have major biological plausibility, and other studies have identified them as risk factors for the mortality of the elderly in the $\mathrm{ICU}^{13,20}$. A lower score was considered for both, however, considering that they represented a lower risk.

Finally, risk was classified as the low, moderate, high or very high possibility of the elderly having an outcome of death in the ICU. The elderly classified as at high or very high risk were observed to have a high mortality rate.

The outcome of death was common $(\geq 10 \%)$ in the present study, justifying the use of the Poisson model, which is more conservative when using relative risk than other statistical methods, such as logistic regression, which uses the odds ratio, and in this situation overestimates RR.

The instrument of prognostic evaluation constructed in this study is suitable for predicting the prognosis of the elderly in ICUs, as it presents an area under the ROC curve of 0.78 , with acceptable power of discrimination, and proved itself sufficiently consistent for a reasonable degree of accuracy in predicting the risk of mortality of elderly persons hospitalized in ICUs. American indices developed for the elderly in ICUs identified an area of 0.7 when using SAPS II and a 0.7 classification tree ${ }^{24}$.

The fact that the instrument used in this study was not compared to a severity index previously used in an ICU, which is considered a gold standard, may represent a limiting factor. However, the authors intend to carry out additional studies among similar populations, as well as to validate the instrument proposed and constructed in this study.

\section{CONCLUSION}

The instrument developed in this study appears to be adequate, objective and easy to apply, with good sensitivity and specificity for identifying the risk of mortality of elderly persons in ICUs. It may be useful in the identification of elderly individuals with risk factors that require greater care, and can therefore be applied in such units.

The identification of the risk of mortality of the elderly in ICUs is important for the support it provides to professionals and, together with institutions, offers the opportunity to evaluate the clinical and hospital practices that may be related to unfavorable outcomes in such units, thus contributing to care planning and early intervention strategies.

It should be emphasized that the instrument developed here is simple to apply, including with respect to its objective variables. It is easy to interpret and its results are easy to identify, and it costs health services nothing. It has a very small number of variables, and can be easily used by nurses, physicians and physiotherapists working in ICUs. Its applications allow the evolution and response of the 
elderly to the therapy performed during their stay in the ICU to be monitored.

As there is growing demand for the hospitalization of the elderly in Brazilian ICUs, the proposal to construct an instrument to assess the prognosis risk of such individuals, as well as being innovative, aims to meet a need arising from this reality.

It is important to carry out additional studies of similar populations, as well as to validate the instrument constructed and proposed in this study.

\section{REFERENCES}

1. Pedrosa IL, Farias MCAD, Silva FA, Cavalcante VRB, Gadelha CS, Schneider RH. Characteristics and prognostic factors of elderly patients in intensive care unit. Int Arch Med. Sect Epidemiol [Internet]. 2015 [acesso em 31 mar. 2017];8(243):18. Disponível em: file://C:/Users/Ivanilda/ Downloads/1345-1-4545-1-10-20151019.pdf

2. Pedreira LCI, Brandão AS, Reis AM. Evento adverso no idoso em Unidade de Terapia Intensiva. Rev Bras Enferm [Internet]. 2013 [acesso em 02 abr. 2017];66(3):429-36. Disponível em: http://www.scielo. br/pdf/reben/v66n3/a19v66n3.pdf

3. Silva Junior JM, Malbouisson LMS, Nuevo HL, Barbosa LGT, Marubayashi LY, Teixeira IC, et al. Aplicabilidade do Escore Fisiológico Agudo simplificado (SAPS 3) em hospitais brasileiros. Rev Bras Anestesiol [Internet]. 2010 [acesso em 04 jul. 2010];60(1):20-31. Disponível em: http://www.scielo. br/pdf/rba/v60n1/v60n1a03.pdf

4. Freitas ERFS. Profile and severity of the patients of intensive care units: prospective application of the APACHE II Index. Rev Latinoam Enferm [Internet]. 2010 [acesso em 08 fev. 2014];18(3):317-23. Disponível em: file://C:/Users/Ivanilda/Downloads/4157-59881-PB.pdf

5. Alves GC, Silva Júnior GB, Lima RSA, Sobral JB, Mota RMS, Abreu KLS, et al. Fatores de risco para óbito em pacientes idosos gravemente enfermos. Rev Bras Ter Intensiva [Internet]. 2010 [acesso em 13 fev. 2014];22(2):138-43. Disponível em: http://www. scielo.br/scielo.php?script=sci_arttext\&pid=S0103507X2010000200007

6. Alves CJ, Franco GPP, Nakata CT, Costa GLG, Costa GLG, Genaro MAS, et al. Avaliação de índices prognósticos para pacientes idosos admitidos em unidades de terapia intensiva. Rev Bras Ter Intensiva [Internet]. 2009 [acesso em 11 ago. 2011];21(1):1-8. Disponível em: http://www.rbti.org.br/download/ artigo_201051819284.pdf
7. Silva LMS, Martins LF, Santos MCFC, Oliveira RM. Índices prognósticos na prática clínica de enfermagem em terapia intensiva: revisão integrativa. Rev Eletrônica Enferm [Internet]. 2014 [acesso em 02 abr. 2017];16(1):179-90. Disponível em: https://www. fen.ufg.br/fen_revista/v16/n1/pdf/v16n1a21.pdf

8. Minne L, Ludikhuize J, Jonge E, Rooij S, AbuHanna A. Prognostic models for predicting mortality in elderly ICU patients: a systematic review. Intensive Care Med [Internet]. 2011 [acesso em 13 jul. 2012];37(8):1258-68. Disponível em: http://link.springer.com/article/10.1007\%2Fs00134011-2265-6\#page-1

9. Rooij SE, Abu-Hanna A, Levi M, Jonge E. Factors that predict outcome of intensive care treatment in very elderly patients: a review. Crit Care [Internet]. 2005 [acesso em 12 mar. 2011];9(4):307-14. Disponível em: http://www.ncbi.nlm.nih.gov/pmc/articles/ PMC1269437/pdf/cc3536.pdf

10. Leite MT, Gonçalves LHT. A enfermagem construindo significados a partir de sua interação social com idosos hospitalizados. Texto \& Contexto Enferm [Internet]. 2009 [acesso em 11 mar. 2011];18(1):108-15. Disponível em: http://www.scielo. br/pdf/tce/v18n1/v18n1a13.pdf

11. Souza VL. Aplicação dos modelos de cox e Poisson para obter medidas de efeito em um estudo de coorte [Tese na Internet]. Rio de Janeiro: Escola Nacional de Saúde Pública Sergio Arouca; 2011 [acesso em 2011 ago. 2013]. Disponível em:http://bases.bireme.br/cgibin/wxislind.exe/iah/online/?IsisScript=iah/iah.xis\& $\mathrm{src}=$ google $\&$ base $=$ LILACS\&lang $=$ p\&next Action $=\ln$ k\&exprSearch=616671\&indexSearch=ID

12. Hartford Institute for Geriatric Nursing. Katz Index of Independence in Activities of Daily Living (ADL) [Internet]. New York: hartfordign; 2005 [acesso em 25 nov. 2005]. Disponível em: http://www. hartfordign.org/ 
13. Machado RL. Modelo para predição de óbito em idosos com sepse grave e choque séptico [dissertação na Internet]. Rio de Janeiro: Faculdade de Medicina da Universidade Federal do Rio de Janeiro; 2008 [acesso em 13 out. 2013]. Disponível em: http://www. livrosgratis.com.br/arquivos_livros/cp078784.pdf

14. Everitt BS. Modern medical statistics. New York: Oxford University Press; 2003.

15. Resolução 466, de 12 de dezembro de 2012. Dispõe sobre as Diretrizes e normas regulamentadoras de pesquisa envolvendo seres humanos. Saúde Legis. 2013. Disponível em: http://bvsms.saude.gov.br/bvs/ saudelegis/cns/2013/res0466_12_12_2012.html

16. Feijó CAR, Leite Júnior FO, Martins ACS, Furtado Júnior AH, Cruz LLS, Menezes FA. Gravidade dos pacientes admitidos à unidade de terapia intensiva de um hospital universitário brasileiro. Rev Bras Ter Intensiva [Internet]. 2006 [acesso em 11 mar. 2011];18(1):18-21. Disponível em: http://www.scielo. $\mathrm{br} / \mathrm{pdf} / \mathrm{rbti} / \mathrm{v} 18 \mathrm{n} 1 / \mathrm{a} 04 \mathrm{v} 18 \mathrm{n} 1$

17. Gorzoni ML, Elisa FAC, Meneses MCL.

Comorbidade, multimorbidade e apresentações atípicas das doenças nos idosos. In: Freitas EV, Py L, editores. Tratado de geriatria e gerontologia. $3^{\text {a }}$. ed. Rio de Janeiro: Koogan; 2011. p. 931- 44.

18. Lucena MVF. Fatores associados à mortalidade em pacientes idosos internados em unidade de terapia intensiva [Dissertação na Internet]. Pernambuco: Universidade Federal de Pernambuco; 2016 [acesso em 02 abr. 2017]. Disponível em: http://repositorio. ufpe.br/bitstream/handle/123456789/17795/

DISSERTA $\%$ C $3 \% 87 \% \mathrm{C} 3 \% 83 \mathrm{O} \% 20$

DE \%20MESTRADO \%20-\%20PDF. pdf? sequence $=1 \&$ is Allowed $=\mathrm{y}$
19. Farfel JM, Franca SA, Sitta MC, Jacob Filho W, Carvalho CR. Age, invasive ventilatory support and outcomes in elderly patients admitted to intensive care units. Age Ageing [Internet] 2009 [acesso em 25 nov. 2013];38(5):515-20. Disponível em: http://www. producao.usp.br/handle/BDPI/21587

20. Biston P, Aldecoa C, Devriendt J, Madl C, Chochrad $\mathrm{D}$, Vincent JL, et al. Outcome of elderly patients with circulatory failure. Intensive Care Med [Internet]. 2014 [acesso em 02 abr. 2017].40(1):50-6. Disponível em: https://link.springer.com/article/10.1007/ s00134-013-3121-7

21. Ferreira LC, Gabriel PASA, Gabriel RA. Trauma e emergências no idoso. In: Freitas EV, Py L, editores. Tratado de geriatria e gerontologia. $3^{\mathrm{a}}$. ed. Rio de Janeiro: Koogan; 2011. p. 1121-26.

22. César LAM. Frequência cardíaca e risco cardiovascular. Rev Assoc Med Bras [Internet]. 2007 [acesso em 14 fev. 2014];53(5):456-9. Disponível em: http://www.scielo.br/pdf/ramb/v53n5/a24v53n5.pdf

23. Netto AP, Raduan RA, Giacaglia L, Sargaço RA, Salles JEN, Leite SAO. Controle da hiperglicemia intra-hospitalar em pacientes críticos e não críticos. Posicionamento Oficial SBD no 02/2011 [Internet]. São Paulo: Sociedade Brasileira de Diabetes; 2011 [acesso em 20 nov. 2013]. Disponível em: http:// www.diabetes.org.br/attachments/posicionamento/ posicionamento-sbd-n-02-2011.pdf

24. Rooij SE, Abu-Hanna A, Levi M, Jonge E. Identification of high-risk subgroups in very elderly intensive care unit patients. Crit Care [Internet]. 2007 [acesso em 17 jan. 2014];11(2):2-9. Disponível em: http://ccforum.com/content/11/2/R33 